\title{
PIJAT OKSITOSIN MENGGUNAKAN FENNEL ESSENTIAL OIL MEMPERCEPAT PENGELUARAN KOLOSTRUM IBU POST PARTUM SECTIO CESAREA
}

\author{
Martina Ekacahyaningtyas, Innez Karunia Mustikarani, \\ Ratih Dwilestari Puji Utami \\ Prodi Sarjana keperawatan dan Profesi Ners, Universitas Kusuma Husada Surakarta \\ mekacahyaningtyas@ukh.ac.id
}

\begin{abstract}
Abstrak
Pendahuluan: Upaya peningkatan pemberian ASI berperan besar terhadap pencapaian penurunan angka kematian bayi dan menurunnya prevalensi gizi kurang pada anak balita. Salah satu komponen nutrisi yang penting pada ASI adalah kolostrum karena mengandung banyak antibodi untuk kekebalan bayi. Ibu melahirkan dengan sectio cesarea mengalami hambatan dalam waktu pengeluaran kolostrum karena efek penggunaan obat-obatan saat dilakukan operasi sectio cesarea dan ibu membutuhkan waktu untuk memulihkan kondisinya akibat nyeri post operasi.

Tujuan: Penelitian ini bertujuan untuk mengetahui pengaruh pijat oksitosin menggunakan fennel essential oil terhadap waktu pengeluaran kolostrum pada ibu post partum sectio cesarea.

Metode: Metode penelitian kuasi eksperimen menggunakan post test only design with control group. Kelompok perlakuan yaitu ibu post partum sectio cesarea yang diberikan pemijatan oksitosin menggunakan fennel essential oil dan kelompok kontrol yaitu ibu post partum sectio cesarea yang dilakukan pemijatan oksitosin tanpa menggunakan fennel essential oil. Sampel sejumlah $30 \mathrm{ibu}$ post operasi sectio cesarea di RSUD Soediran Mangun Soemarso Wonogiri. Analisis penelitian menggunakan uji Mann Whitney.

Hasil: Penelitian ini didapatkan hasil nilai $\mathrm{p}$ value 0,002 yang berarti $\mathrm{p}$ value $<0,05$ sehingga Ho ditolak dan Ha diterima.

Kesimpulan: Ada pengaruh pijat oksitosin menggunakan fennel essential oil terhadap waktu pengeluaran kolostrum pada ibu post partum sectio cesarea. Rekomendasi yang dapat diberikan adalah ibu post partum section caesarea dapat dilakukan pijat oksitosin menggunakan fennel essential oil secara teratur untuk mempercepat pengeluaran kolostrum.
\end{abstract}

Kata kunci : Ibu post partum sectio cesarea, pijat oksitosin, fennel essential oil

\begin{abstract}
Background: Efforts to increase breastfeeding play a significant role in reducing infant mortality and reducing malnutrition in toddlers. One important component of nutrition in breast milk is colostrum because it contains antibodies for the infants' immunity. Mothers giving birth with cesarean section experience obstacles in releasing colostrum because of the effects of drugs usage during cesarean sectio surgery and the mothers need time to restore their condition due to post operation pain.

Purpose: This study aims to determine the effect of oxytocin massage using fennel essential oil on release time of colostrum in postpartum cesarean mothers.

Methods: The quasi-experimental research method uses the post test only design with control group. The treatment group is post partum sectio cesarea mothers who are given oxytocin massage using fennel essential oil and the control group is post partum cesarea mothers who get oxytocin massage without fennel essential oil. Samples are 30 post-
\end{abstract}


operative cesarean mothers in Soediran Mangun Soemarso Hospital, Wonogiri. The research analysis uses the Mann Whitney test.

Results: This research shows that the value of $p$ value is 0.002 , which means $p$ value $<0.05$ so that Ho is rejected and $\mathrm{Ha}$ is accepted.

Conclusion: There is an effect of oxytocin massage using fennel essential oil on the colostrum release time in postpartum cesarean mothers. The recommendation that can be given is that the post partum caesarea mother can do oxytocin massage using fennel essential oil regularly to accelerate the release of colostrum.

Keywords: Post partum sectio cesarea mother, oxytocin massage, fennel essential oil.

\section{Pendahuluan}

Menyusui merupakan salah satu cara yang paling efektif untuk memastikan kesehatan dan kelangsungan hidup anak (WHO, 2014). ASI diperlukan karena merupakan nutrisi penting untuk bayi. ASI mempunyai komposisi yang seimbang dan sesuai dengan kebutuhan bayi. Hasil Riset Kesehatan Dasar (Riskesdas, 2018) menunjukkan proporsi pemberian ASI pada bayi usia 0-5 bulan adalah bayi yang mendapatkan ASI eksklusif sebanyak 37,3 $\%$, bayi yang mendapatkan ASI parsial sebanyak 9,3\% dan bayi yang mendapatkan ASI predominan sebanyak 3,3\%. Proporsi pemberian ASI eksklusif turun dibandingkan pada Riskesdas tahun 2013 yaitu sebanyak 38\%. Sedangkan di Provinsi Jawa Tengah bayi yang mendapatkan ASI eksklusif sekitar $33 \%$.

Salah satu komponen dari ASI yang penting adalah kolostrum. Kolostrum dalam ASI adalah merupakan cairan pra-susu (cairan yang keluar sebelum ASI sebenarnya berproduksi) dan cairan ini berwarna kekuningan yang keluar pada awal-awal masa menyusui, yaitu pada 24-36 jam pertama setelah proses melahirkan selesai (Murray, SS \& Mckinney, ES, 2014). Ibu yang melahirkan melalui proses sectio cesarea mengalami hambatan dalam waktu pengeluaran kolostrum karena beberapa hal. Faktor-faktor yang mempengaruhi diantaranya kadar hormon prolaktin dan oksitosin yang dapat mempengaruhi pengeluaran kolostrum pada ibu dan penggunaan obat-obatan saat dilakukan operasi sectio cesarea. Obat-obatan yang diberikan pada saat operasi sectio cesarea digunakan untuk mengurangi rasa nyeri pada saat operasi, namun setelah operasi selesai nyeri yang timbul akibat efek yang hilang dari obat bius dapat mempengaruhi ibu dalam memberikan perawatan pada bayi, sehingga 
dapat menyebabkan ibu menunda untuk menyusui sehingga menimbulkan keterlambatan dalam pengeluaran kolostrum (Davidson, MR, et al. 2012).

ASI dikeluarkan melalui proses antara rangsangan mekanik, saraf dan bermacam-macam hormon yang berpengaruh terhadap pengeluaran oksitosin. Terdapat dua hal yang mempengaruhi upaya pengeluaran ASI yaitu produksi dan pengeluaran (Klossner, N. Jayne, 2010). Produksi ASI dipengaruhi oleh hormon prolaktin sedangkan pengeluaran dipengaruhi oleh hormon oksitosin Pengeluaran hormon oksitosin selain dipengaruh oleh isapan bayi juga dipengaruhi oleh reseptor yang terletak pada sistem duktus, bila duktus melebar atau menjadi lunak maka secara reflektoris dikeluarkan oksitosin oleh hipofise yang berperan untuk memeras air susu dari alveoli (Chapman \& Durham, 2010).

Hormon oksitosin akan keluar melalui rangsangan ke puting susu melalui isapan mulut bayi atau melalui pijatan pada tulang belakang ibu bayi, dengan dilakukan pijatan pada tulang belakang ibu akan merasa tenang, rileks, meningkatkan ambang rasa nyeri dan mencintai bayinya, sehingga dengan begitu hormon oksitosin keluar dan ASI pun cepat keluar. Melalui pijatan atau rangsangan pada tulang belakang, neurotransmitter akan merangsang medulla oblongata langsung mengirim pesan ke hypothalamus di hypofise posterior untuk mengeluarkan oksitosin sehingga menyebabkan payudara mengeluarkan air susunya (Endah SN dan Masdinarsah, Imas, 2011).

Tindakan pijat oksitosin dapat dilakukan dengan menggunakan fennel essential oil (Foeniculum Vulgare Mill) atau bisa disebut minyak adas. Menurut penelitian yang dilakukan oleh Badgujar, SB (2014), adas telah digunakan dalam pengobatan tradisional untuk berbagai macam penyakit yang berkaitan dengan sistem pencernaan, endokrin, reproduksi, dan pernafasan. Selain itu, juga digunakan sebagai agen galaktagog untuk ibu menyusui (Manzoor A.Rather, 2016)

\section{Tujuan}

Tujuan dari penelitian ini adalah untuk mengetahui pengaruh pijat oksitosin menggunakan fennel essential oil terhadap waktu pengeluaran kolostrum pada ibu post partum sectio cesarea. 


\section{Metode}

Penelitian ini dilakukan di RSUD Soediran Mangun Soemarso Wonogiri pada bulan Juli-September 2018 menggunakan metode kuasi eksperimen dengan rancangan post test only design with control group yang terdiri dari kelompok perlakuan yaitu ibu post partum yang diberikan pemijatan oksitosin menggunakan fennel essential oil dan kelompok kontrol yaitu ibu post partum yang dilakukan pemijatan oksitosin tanpa menggunakan fennel essential oil.

Teknik sampel yang digunakan yaitu consecutive sampling sesuai data yang dibutuhkan dengan menggunakan kriteria inklusi dan kriteria eksklusi. Kriteria inklusi meliputi ibu post partum sectio cesarea yang 12 jam pertama belum mengeluarkan kolostrum, primigravida maupun multigravida, belum mendapatkan tindakan terapi pijat oksitosin dan setuju ikut serta dalam penelitian. Sedangkan kriteria eksklusi meliputi terdapat komplikasi post partum misalnya perdarahan dan alergi terhadap fennel essential oil. Populasi dalam penelitian ini adalah sebanyak 33 ibu post partum sectio cesarea 12 jam pertama yang belum mengeluarkan kolostrum di Rumah Sakit Soediran Mangun Soemarso Wonogiri sehingga didapatkan besar sampel sebanyak 30 orang responden. Analisis data menggunakan uji Mann Whitney.

\section{Hasil}

Penelitian ini diikuti oleh 30 responden ibu post partum dengan sectio caesarea yang 12 jam pertama belum mengeluarkan kolostrum. Berikut ini adalah hasil penelitian karakteristik responden meliputi umur, pendidikan, pekerjaan, waktu pengeluaran kolostrum.

Tabel 1. Karakteristik responden menurut umur $(\mathrm{n}=30)$

\begin{tabular}{ccccc}
\hline $\begin{array}{c}\text { Klasifikasi umur responden } \\
\text { (tahun) }\end{array}$ & \multicolumn{2}{c}{ Kelompok kontrol } & \multicolumn{2}{c}{ Kelompok perlakuan } \\
& Frekuensi & $\%$ & Frekuensi & $\%$ \\
\hline $17-25$ (remaja akhir) & 4 & 26,7 & 3 & 20 \\
$26-35$ (dewasa awal) & 11 & 73,3 & 10 & 66,7 \\
$36-45$ (dewasa akhir) & - & - & 2 & 13,3 \\
\hline
\end{tabular}

Tabel 1. Menunjukkan bahwa ibu melahirkan sectio cesarea terbanyak pada rentang usia 26-35 (dewasa awal) yaitu sejumlah 11 orang (73,3\%) pada kelompok kontrol dan sejumlah 10 orang $(66,7 \%)$ pada kelompok perlakuan. 
Tabel 2. Karakteristik responden menurut pendidikan $(\mathrm{n}=30)$

\begin{tabular}{lcccc}
\hline $\begin{array}{c}\text { Klasifikasi umur } \\
\text { responden }\end{array}$ & \multicolumn{2}{c}{ Kelompok kontrol } & \multicolumn{2}{c}{ Kelompok perlakuan } \\
& Frekuensi & $\%$ & Frekuensi & $\%$ \\
\hline Sarjana & 2 & 13,3 & 3 & 20 \\
D3 & 3 & 20 & 1 & 6,7 \\
SMA & 9 & 60 & 9 & 60 \\
SMP & 1 & 6,7 & 2 & 13,3 \\
\hline
\end{tabular}

Tabel 2. Menunjukkan bahwa ibu melahirkan sectio cesarea terbanyak memiliki pendidikan SMA yaitu sejumlah 9 orang pada kelompok kontrol $(60 \%)$ dan sejumlah 9 orang (60\%) pada kelompok perlakuan.

Tabel 3. Karakteristik responden menurut pekerjaan $(n=30)$

\begin{tabular}{lcccc}
\hline $\begin{array}{l}\text { Klasifikasi umur } \\
\text { responden }\end{array}$ & Kelompok kontrol & \multicolumn{2}{c}{ Kelompok perlakuan } \\
\hline PNS & Frekuensi & $\%$ & Frekuensi & $\%$ \\
\hline Swasta & - & - & 2 & 13,3 \\
\hline IRT & 9 & 60 & 7 & 46,7 \\
\hline
\end{tabular}

Tabel 3. Menunjukkan bahwa ibu melahirkan sectio cesarea terbanyak memiliki pekerjaan swasta yaitu sejumlah 9 orang (60\%) pada kelompok kontrol dan sejumlah 7 orang $(46,7)$ pada kelompok perlakuan.

Tabel 4. Waktu pengeluaran kolostrum $(\mathrm{n}=30)$

\begin{tabular}{lcccc}
\hline $\begin{array}{c}\text { Waktu pengeluaran } \\
\text { kolostrum }\end{array}$ & \multicolumn{2}{c}{ Kelompok kontrol } & \multicolumn{2}{c}{ Kelompok perlakuan } \\
& Frekuensi & $\%$ & Frekuensi & $\%$ \\
\hline$<24$ jam & 3 & 20 & 11 & 73,3 \\
$24-36$ jam & 9 & 60 & 4 & 26,7 \\
$>36$ jam & 3 & 20 & - & -
\end{tabular}

Tabel 4. Menunjukkan bahwa waktu pengeluaran kolostrum pada kelompok kontrol (pijat oksitosin tanpa menggunakan fennel essential oil) paling banyak antara 24-36 jam yaitu sebanyak 9 orang (60\%) sedangkan waktu pengeluaran kolostrum pada kelompok perlakuan (pijat oksitosin menggunakan fennel essential oil) paling banyak pada $<24$ jam yaitu sejumlah 11 orang $(73,3 \%)$.

Sedangkan hasil analisis bivariat menggunakan uji Mann Whitney adalah sebagai berikut:

Tabel 5. Uji Mann Whitney

$\frac{.002}{\text { Asymp Sig (2 tailed) }}$ value $<0,05)$ sehingga Ho ditolak artinya ada pengaruh pijat oksitosin 
menggunakan fennel essential oil terhadap waktu pengeluaran kolostrum pada ibu post partum sectio cesarea.

\section{Pembahasan}

Pada penelitian ini, klasifikasi umur responden yang paling banyak adalah pada dewasa awal (26-35 tahun). Hal ini menunjukkan bahwa masyarakat mempunyai kesadaran yang tinggi untuk melakukan kehamilan dan persalinan di rentang usia pada masa reproduksinya. Pada ibu hamil usia ini dianggap ideal untuk menjalani kehamilan dan proses persalinan. Direntang usia ini kondisi fisik wanita dalam keadaan prima dan secara umum siap merawat dan menjaga kehamilannya, rahim juga sudah mampu memberi perlindungan atau kondisi yang maksimal untuk kehamilan. Pada rentang masa reproduksi merupakan waktu yang efektif untuk hamil dan melahirkan karena di rentang usia sebelumnya (remaja akhir) organ reproduksi dan kejiwaan belum matang dan sempurna sehingga beresiko untuk kehamilannya. Sedangkan masa dewasa akhir merupakan masa yang beresiko karena semakin tuanya umur ibu maka kemungkinan terkena penyakit komplikasi akan semakin tinggi sehingga beresiko terhadap kehamilannya (Davidson, MR, et al. 2012)

Hasil penelitian ini tidak sesuai teori yang menyatakan bahwa kelompok usia 35 tahun merupakan usia terbanyak dilakukan sectio cesarea. Hal ini mungkin dapat disebabkan karena terjadinya sectio cesarea di umur 20-35 tahun karena faktor komplikasi pada persalinan yang dapat menyebabkan kematian atau kesakitan pada ibu dan bayinya. Komplikasi yang mungkin timbul saat kehamilan juga dapat mempengaruhi jalannya persalinan sehingga sectio cesarea dianggap sebagai cara terbaik untuk melahirkan janin. Hasil penelitian ini sesuai dengan penelitian yang dilakukan M, Rasdiana, et al (2014) yang menyatakan bahwa mayoritas kelompok umur yang dilakukan persalinan secara sectio cesarea adalah 20-35 tahun.

Sesuai dengan hasil penelitian diketahui jumlah responden menurut tingkat pendidikan pada paling banyak adalah SMA yaitu sejumlah 9 orang pada kelompok kontrol (60\%) dan sejumlah 9 orang $(60 \%)$ pada kelompok perlakuan. Pendidikan adalah sesuatu yang dapat membawa seseorang untuk memiliki ataupun meraih wawasan dan pengetahuan seluas-luasnya. Orang-orang yang 
memiliki pendidikan yang lebih tinggi akan memiliki wawasan dan pengetahuan yang lebih luas jika dibandingkan yang lebih rendah (Notoatmojo, 2012). Orang yang mempunyai pendidikan tinggi akan mudah untuk memahami tentang resiko persalinan yang akan dihadapi. Hal ini sesuai dengan hasil penelitian bahwa paling banyak responden berpendidikan tinggi sehingga besar kemungkinan bagi mereka untuk dapat mengantisipasi resiko pada persalinan. Ibu yang memiliki tingkat pendidikan tinggi cenderung lebih memperhatikan kesehatannya selama kehamilan bila dibanding dengan ibu yang tingkat pendidikannya lebih rendah. Semakin tinggi pendidikan formal seorang ibu diharapkan semakin meningkat pengetahuan dan kesadarannya dalam mengantisipasi kesulitan dalam kehamilan dan persalinannya, sehingga timbul dorongan untuk melakukan pengawasan kehamilan secara berkala dan teratur. Sehingga persalinan operasi sectio cesarea lebih berpeluang terjadi pada ibu dengan tingkat pendidikan yang lebih tinggi.

Semakin tinggi pendidikan seseorang maka semakin mudah baginya untuk mengerti dan memahami tentang risiko proses persalinan yang akan dihadapi. Hal tersebut mempengaruhi pembuatan keputusan apakah akan melakukan persalinan secara sectio cesarea ketika diketahui adanya komplikasi dalam kehamilan dan persalinan. Hal ini sesuai dengan hasil penelitian Sihombing, Novianti (2017) yang menyatakan bahwa jumlah ibu yang melakukan operasi sectio cesarea paling banyak adalah ibu yang berpendidikan tinggi.

Sesuai dengan hasil penelitian diketahui jumlah responden menurut pekerjaan yang paling banyak adalah swasta yaitu sejumlah 9 orang $(60 \%)$ pada kelompok kontrol dan sejumlah 7 orang $(46,7)$ pada kelompok perlakuan. Pekerjaan seseorang akan menggambarkan aktivitas dan tingkat kesejahteraan ekonomi yang didapat. Hasil penelitian ini sesuai dengan hasil analisa data Riskesdas (2013) ini diketahui bahwa ibu yang memiliki peluang untuk bersalin secara operasi sectio cesarea adalah ibu yang bertempat tinggal di kota, dengan tingkat pendidikan yang lebih tinggi yaitu lulusan D3/Perguruan Tinggi, secara status ekonomi berada pada kepemilikan kuantil tertinggi (ekonomi atas) dan bekerja pada sektor formal sebagai pegawai swasta.

Ibu yang bekerja mempunyai tingkat pengetahuan yang lebih baik dari pada ibu yang tidak bekerja, karena pada ibu yang bekerja akan lebih banyak 
memiliki kesempatan untuk berinteraksi dengan orang lain, sehingga lebih mempunyai banyak peluang juga untuk mendapat informasi seputar keadaan kesehatannya salah satu contoh informasi deteksi dini faktor resiko pada saat kehamilan (M, Rasdiana, et al, 2014). Memiliki status sebagai seorang pekerja yang terikat dengan waktu juga mendorong ibu memilih persalinan sectio cesarea sebagai metode persalinan karena ibu yang bekerja akan ditetapkan kapan mereka harus kembali bekerja setelah persalinan. Kondisi inilah yang membuat peluang terjadinya persalinan secara operasi sectio cesarea menjadi lebih besar terjadi pada ibu pekerja (Sihombing, Novianti, 2017).

Pada penelitian ini, waktu pengeluaran kolostrum pada kelompok kontrol (pijat oksitosin tanpa menggunakan fennel essential oil) paling banyak antara 24-36 jam yaitu sebanyak 9 orang (60\%) sedangkan waktu pengeluaran kolostrum pada kelompok perlakuan (pijat oksitosin menggunakan fennel essential oil) paling banyak pada $<24$ jam yaitu sejumlah 11 orang $(73,3 \%)$.Produksi kolostrum pada ibu sudah dimulai saat kehamilan, namun tidak disekresikan sampai saat setelah persalinan, hal ini disebabkan karena masih tingginya kadar hormon esterogen yang menghambat proses pengeluaran kolostrum. Waktu pengeluaran kolostrum dipengaruhi oleh beberapa hal salah satunya adalah jenis persalinan. Ibu yang mengalami persalinan secara sectio cesarea biasanya memerlukan waktu yang lama untuk mengeluarkan kolostrum. Sehingga penelitian ini sesuai dengan hasil penelitian yang dilakukan oleh Dina, Almas Azifah, et al (2017) bahwa ibu post operasi sectio cesarea rata-rata memiliki waktu yang lama pada pengeluaran kolostrum yaitu dengan waktu > 120 menit.

Mekanisme penghambat pengeluaran kolostrum pada ibu yang mengalami persalinan secara sectio cesarea terletak pada nyeri dan kecemasan ibu, obat-obatan yang diberikan, baik induksi operasi maupun analgesia serta keterlambatan pemberian ASI yang pertama karena ibu memerlukan waktu lebih lama dalam pemulihan pasca melahirkan dibandingkan dengan persalinan normal. Pada persalinan sectio cesarea, stres pada ibu dapat disebabkan oleh rasa nyeri setelah efek anastesi menghilang. Stress pada ibu post partum akan disertai peningkatan sekresi Adrenokortikotropik Hormon (ACTH) oleh kelenjar hipofisis anterior yang diikuti dengan peningkatan sekresi hormon 
adrenokortikal berupa kortisol dalam waktu beberapa menit. Sekresi kortisol yang tinggi dapat menghambat transportasi hormon oksitosin dalam sekresinya, sehingga dapat menghambat pengeluaran produk ASI termasuk kolostrum. (Dina, Almas Azifah, et al, 2017)

Hasil analisis bivariat dengan menggunakan uji Mann Whitney menunjukkan $\mathrm{p}$ value 0,002 ( $\mathrm{p}$ value $<0,05$ ) sehingga Ho ditolak artinya ada pengaruh pijat oksitosin menggunakan fennel essential oil terhadap waktu pengeluaran kolostrum pada ibu post partum sectio cesarea. Berdasarkan teori terdapat beberapa hal yang dapat dilakukan untuk merangsang pengeluaran kolostrum. Salah satunya adalah dengan melakukan pijat oksitosin. Kecepatan waktu pengeluaran kolostrum lebih cepat pada kelompok perlakuan dibandingkan kelompok kontrol. Hal ini dapat terjadi karena kandungan fennel essential oil yaitu anethole dapat sebagai agen galaktagog untuk ibu menyusui. Foeniculum vulgare telah digunakan sebagai agen estrogenik yang berefek pada meningkatnya sekresi susu (Badgujar, SB, 2014).

Selain itu, fennel essential oil yang digunakan untuk pijat oksitosin di daerah punggung menimbulkan rasa hangat dan nyaman pada ibu. Pijatan di daerah tulang belakang ini juga akan merileksasikan ketegangan dan menghilangkan stress sehingga neurotransmitter akan merangsang medulla oblongata langsung mengirim pesan ke hypothalamus di hypofise posterior untuk mengeluarkan oksitosin sehingga menyebabkan payudara mengeluarkan air susunya (Zamzara, Rezza Fahlilani, et al, 2015)

\section{Kesimpulan}

Kesimpulan dari penelitian ini adalah terdapat pengaruh pijat oksitosin menggunakan fennel essential oil terhadap waktu pengeluaran kolostrum pada ibu post partum sectio cesarea. Hal ini menunjukkan bahwa pijat oksitosin menggunakan fennel essential oil dapat digunakan sebagai alternatif untuk mempercepat waktu pengeluaran kolostrum.

Saran yang dapat disampaikan adalah petugas kesehatan diharapkan dapat memberikan informasi dan edukasi kepada ibu, serta dapat memotivasi ibu post partum sectio cesarea agar dapat menyusui bayinya sesegera mungkin setelah melahirkan. Salah satu cara yang dapat diterapkan untuk menstimulasi 
produksi ASI adalah melakukan pijat oksitosin dengan menggunakan fennel essential oil.

\section{Daftar pustaka}

Badgujar, SB , Patel VV, Bandivdekar, AH. 2014. Foeniculum vulgare Mill: A Review of Its Botany, Phytochemistry, Pharmacology, Contemporary Application, and Toxicology. Biomed Res Int. 2014; 2014: 842674. https://www.ncbi.nlm.nih.gov/pmc/articles/PMC4137549/ diakses tanggal 15 Februari 2018

Chapman, L. \& Durham, R., 2010. Maternal-Newborn Nursing_The Critical Components of Nursing Care, Philadelphia: F.A. Davis Company.

Dina, Almas Azifah, Sumarah, Kurniati, Ana (2017). Jenis Persalinan Dengan Waktu Pengeluaran Kolostrum Pada Ibu Bersalin Kala Iv Di Kota Yogyakarta. Jurnal Kesehatan Ibu dan Anak, Volume 11, No.2, November 2017 , hal 43-48. file:///C:/Documents\%20and\%20Settings/prodi/My\%20Documents/Downl oads/39-Article\%20Text-62-1-10-20180306.pdf diakses tanggal 2 September 2018

Davidson, Michele R., London, Marcia L., Ladewig, Patricia A. Wieland. 2012. Olds' Maternal-Newborn Nursing \& Women's Health Across The Lifespan. Pearson : United State of America

Endah, SN dan Masdinarsah, Imas. 2011. Pengaruh Pijat Oksitosin terhadap Pengeluaran Kolostrum pada Ibu Post Partum Di Ruang Kebidanan Rumah Sakit Muhammadiyah Bandung Tahun 2011. Jurnal Kesehatan Kartika http://stikesayani.ac.id/publikasi/ejournal/filesx/2011/201112/201112-001.pdf diakses tanggal 3 Februari 2018

Kementrian Kesehatan RI, 2013. InfoDATIN Pusat Data dan Informasi Kementrian Kesehatan RI. Available at: http://www.depkes.go.id/resources/download/pusdatin/infodatin/infodatinasi.pdf. diakses tanggal 5 Februari 2018

Kementrian Kesehatan RI, 2016. Data dan Informasi Profil Kesehatan Indonesia 2016. Pusat data dan Informasi Kementrian Kesehatan RI 2017. http://www.depkes.go.id/resources/download/pusdatin/lainlain/Data\%20dan\%20Informasi\%20Kesehatan\%20Profil\%20Kesehatan\%2 0Indonesia\%202016\%20-\%20\%20smaller\%20size\%20-\%20web.pdf diakses tanggal 16 Februari 2018

Klossner, N. Jayne \& Hatfield, Nancy T. 2010. Introductory Maternity \& Pediatric Nursing. Lippincott Williams \& Wilkins 
Manzoor A.Rather ${ }^{\mathrm{a}}$, Bilal A.Dar ${ }^{\mathrm{a} S h a h n a w a z, ~ N . S o f i}{ }^{\mathrm{a}}$ Bilal A.Bhat ${ }^{\mathrm{a}}$ Mushtaq A.Qurishib. (2016) Foeniculum vulgare: A comprehensive review of its traditional use, phytochemistry, pharmacology, and safety. Arabian Journal of Chemistry https://www.sciencedirect.com/science/article/pii/S1878535212000792 diakses tanggal 3 Februari 2018

Muhammad, Rasdiana; Rahayuningsih, Faizah Betty; Yulian, Vinami (2014). Karakteristik ibu yang mengalami persalinan dengan sectio cesarea di rumah sakit umum daerah moewardi surakarta tahun 2014 http://eprints.ums.ac.id/42452/26/NASKAH\%20PUBLIKASI.pdf diakses tanggal 10 September 2018

Murray, Sharon Smith \& Mckinney, Emily Slone. 2014. Foundations Of Maternal-Newborn and Women's Health Nursing. 6th edition. Elsevier : United States of America.

SDKI, 2012. Survei Demografi Kesehatan Indonesia Tahun 2012, Available at: http://www.bkkbn.go.id/litbang/pusdu/Hasil Penelitian/SDKI 2012/Laporan Pendahuluan SDKI 2012.pdf.

Sihombing, Novianti, Saptarinia, Ika , Kumala, Dwi Sisca (2017) Determinan Persalinan Sectio cesarea Di Indonesia (Analisis Lanjut Data Riskesdas 2013). Jurnal Kesehatan Reproduksi, 8(1), 2017: 63-75 DOI: 10.22435/kespro.v8i1.6641.63-75.

https://media.neliti.com/media/publications/108556-ID-none.pdf diakses tanggal 7 September 2018

Sunaini. 2016. Pengaruh Ekstrak Ethanol Daun Adas (Foeniculum Vulgare Mill) Pada Induk Tikus (Rattus Norvegicus) Masa Laktasi Terhadap Pertumbuhan Anak. Skripsi. Program Studi Biologi Fakultas Sains Dan Teknologi Uin Sunan Kalijaga. http://digilib.uinsuka.ac.id/22863/1/11640020_BAB-I_IV-atau-V_DAFTAR-

PUSTAKA.pdf diakses tanggal 2 Februari 2018

WHO, 2014. Breastfeeding, Available at: http://www.who.int/topics/breastfeeding/en/

Zamzara, Rezza Fahlilani; Ernawati, Dwi; Susanti, Ari (2015) Pengaruh Pijat Oksitosin Terhadap Waktu Pengeluaran Kolostrum Ibu Post Partum Sectio Caesaria. UNUSA. http://journal.unusa.ac.id/index.php/jhs/article/download/75/67 diakses tanggal 6 Februari 2018 